Yale Studies in English 
Yale Studies in English publishes books on English, American, and Anglophone literature developed in and by the Yale University community. Founded in 1898 by Albert Stanburrough Cook, the original series continued into the 1970s, producing such titles as The Poetry of Meditation by Louis Martz, Shelley's Mythmaking by Harold Bloom, The Cankered Muse by Alvin Kernan, The Hero of the Waverley Novels by Alexander Welsh, John Skelton's Poetry by Stanley Fish, and Sir Walter Raleigh: The Renaissance Man and His Roles by Stephen Greenblatt. With the goal of encouraging publications by emerging scholars alongside the work of established colleagues, the series has been revived for the twenty-first century with the support of a grant from the Andrew W. Mellon Foundation and in partnership with Yale University Press. 


\section{The Buddha in the Machine}

Art, Technology,

and the Meeting of

East and West

\section{R. John Williams}

Yale UNIVERsity PRESS

New Haven and London 
Published with the assistance of the Frederick W. Hilles Publication Fund of Yale University.

Copyright (C) 2014 by R. John Williams.

All rights reserved.

This book may not be reproduced, in whole or in part, including illustrations, in any form (beyond that copying permitted by Sections 107 and 108 of the U.S. Copyright Law and except by reviewers for the public press), without written permission from the publishers.

"All Watched Over by Machines of Loving Grace" from The Pill versus the Springhill Mine Disaster by Richard Brautigan. Copyright (C) 1965 by Richard Brautigan. Reprinted by permission of Houghton Mifflin Harcourt Publishing Company. All rights reserved.

Yale University Press books may be purchased in quantity for educational, business, or promotional use. For information, please e-mail sales.press@yale.edu (U.S. office) or sales@yaleup.co.uk (U.K. office).

Designed by Lindsey Voskowsky.

Set in Scala type by Westchester Publishing Services.

Printed in the United States of America.

Library of Congress Cataloging-in-Publication Data

Williams, R. John.

The Buddha in the machine : art, technology, and the meeting of East and West / R. John Williams.

pages $\mathrm{cm}$. - (Yale studies in English)

Includes bibliographical references and index.

ISBN 978-0-300-19447-0 (cloth : alk. paper)

1. East and West. 2. Arts and society. 3. Aesthetics, Oriental. 4. Technology-Psychological aspects.

5. Technology-Social aspects-Western countries.

I. Title.

$$
\begin{aligned}
& \text { CB251.W47 } 2014 \\
& \text { 306-dc23 }
\end{aligned}
$$

2013044488

A catalogue record for this book is available from the British Library.

This paper meets the requirements of ANSI/NISO Z39.48-1992 (Permanence of Paper).

10987654321

Frontispiece: Wang Zi Won, Mechanical Xanadu (2011) (image courtesy of Wang Zi Won). 
For Brooke 
This page intentionally left blank 